\title{
Improving Self-Confidence of the Third Grade Students of Sman 15 Makassar to Speak English Through English Contest Technique (ECT)
}

\author{
M. Dahlan Bahang*, Arma Amir Hamzah, Darma S. Lanre \\ English Education of STKIP-YPUP Makassar, South Celebes, Indonesia.
}

\author{
How to cite this paper: M. Dahlan Ba- \\ hang, Arma Amir Hamzah, Darma S. La- \\ nre. (2020). Improving Self-Confidence of \\ the Third Grade Students of Sman $15 \mathrm{Ma}$ \\ kassar to Speak English Through English \\ Contest Technique (ECT). The Education- \\ al Review, USA, 4(6), 128-134. \\ DOI: $10.26855 /$ er.2020.06.002 \\ Received: April 15, 2020 \\ Accepted: May 28, 2020 \\ Published: June 24, 2020 \\ Corresponding author: M. Dahlan \\ Bahang, Department of English, Eng- \\ lish Education of STKIP-YPUP Ma- \\ kassar, South Celebes, Indonesia. \\ Email: mdahlan.hbahang@gmail.com
}

\begin{abstract}
The objective of this research is to find out English Contest Technique in improving the self-confidence of the third grade students to speak English. In this research, the researcher uses pre-experimental method. The total sample was 42 students and it used cluster sampling technique. The results showed that the students' mean scores in pre-test of the first cycle was 5.29 and the mean score of the second cycle was 6.62. Based on the data above, the researcher concluded that the use of English Contest Technique can improve the third grade students' self-confidence in speaking English.
\end{abstract}

Keywords

English Contest Technique, Speaking Improvement

\section{Introduction}

English subject is taught as a compulsory subject in a secondary school and in some tertiary levels in Indonesia. It is one of the subjects in the core of program of curriculum. One of the curricular objectives of English teaching in Indonesia is to enable the students to speak English. This makes challenging to the English teachers to make the students master it according to curriculum demand. English subject is still not yet given a good result which is expected or the result of the outcome is unsatisfactory. Therefore, the English teacher should look for the effort on searching and creating a new technique or models in presenting materials in order to increase the acquirement in English.

There are many English teachers make an effort to make their classes interesting with various methods, techniques with instruments and materials in order to stimulate the students to learn English skills effectively. In oral English class (speaking) for example, the students should be served with conductive learning activity so that they can practice English as well as possible. The first thing the teacher should do is to create the best conditions for learning as an instrument to see the learning takes place. In other words, the teachers have responsibility to create a situation and provide opportunities and stimulate the students to communicate orally with the English that they may have at disposal. The students should be given confidence in their ability to learn to speak. 
In teaching and learning speaking, there are many handicaps or constrains. One of them is the students' low confidence in speaking and they thought English particularly speaking is very difficult and they did not know what the usefulness of English subject. In this situation, the English teacher should be more creative and determine ways and techniques to increase the students' self-confidence in speaking.

Another problem is the time allocated for speaking class is very limited. On the other side, the academic setting cannot always provide an ample opportunity for students to practice the English language and sufficient target language exposure to acquire. If these two things are not well managed, the students cannot benefit much from the learning activities and thus will give result in inadequate target language proficiency and fluency. In order to bridge the gap, a teacher should make the most of classroom sessions and create learning interaction in order that the students can maximally be exposed to practice their speaking in the class (Noni, 2013).

In relation to the speaking skill, the success in a foreign language teaching depends not only on the quality of the basic program but also on the flexibility and the ability of the teacher in managing and using the program including the technique in presenting material. The teacher in this case has to choose the alternative technique or strategy in teaching English language.

According to the ecological view, the condition and situation is the main factor of the successful of the process which including the approach and the technique that might influence the interest of the students in learning. In this case, the English teacher should not run away from the problem but how to get rid of and find out the alternative way in teaching in order to gain the improvement in teaching and learning process. In other words at the students' skill in speaking will be improved.

In this research, the researcher would like to propose "Contest technique in teaching Speaking". This technique is expected to be meaningful effort in improving the students’ self-confidence in speaking skill.

\section{Problem Statements}

The unsuccessfulness of the teaching of English speaking is caused by many aspects such as the lack of vocabulary, the lack of grammar, the lack of practicing, and the lack of the students' self-confidence and lastly of course the lack of technique in teaching speaking.

Adler in Lauser (1997), states that self-confidence is one of the important human needs. Someone who has high confidence can do any activity without any doubt. Therefore, the writer proposes "English Contest technique" to be investigated in relation to the improvement of the students' self-confidence in speaking skill.

The objective of this research is to find out whether the students' self-confidence can be improved by using English contest technique and to find out whether the students' speaking skill can be improved by using English contest technique at the third grade students of SMAN 15 Makassar.

The result of the research was expected to be useful information to the English teachers of SMA about teaching speaking through contest technique. Finally, the result would be very useful for the improvement of teaching English and the professional of the teacher himself and finally it was hoped to be useful information for other researchers.

The scope of the research included self-confidence and speaking improvement. The study will focus on teaching speaking through contest technique. It is not recommend to be the best way of teaching speaking but to elaborate and the detail way that can be effectively be used to improve the students speaking skill.

\section{Review of Related Literature}

Many studies have been performed by other researches related to the use of strategies, approaches or media in im- 
proving the learners to learn speaking. Some of them were mentioned with their reported as follows:

According to Penny (2016), she said that one of the problems that can be found that the students are easier to use their mother tongue in their class because it looks naturally. Therefore, most of the students are not disciplined in using the target language in the learning process. So many students are hard to pronounce words or explain something. Another problem is the lack of students' participation in the classroom. For example, when the teacher dominates the activity in the classroom, the students may feel like they do not have enough chance to participate actively. The participation may result in lack of motivation which may influence students' speaking skill. Middwson (2011) states that an act of communication through speaking is commonly perform from face to face interaction and occurs as part of dialogue or rather of verbal exchange. River (1968) argues that the teacher will need to give the hardest ample opportunities to practice the speaking skill. This means that practice is needed to overcome the problem of speaking faced by the students who learn a foreign language. This means that the practice is needed to overcome the problem of speaking faced by the students who learn a foreign language. Hariyati (2018) stated that ice breakers (two truths and a lie) on her pre-experimental research with pre-test and post-test design. It was concluded at EFL learners. The result showed that the mean score of post-test was higher than the mean score of pre-test.

Speaking in front of the people is an activity which can give someone high degree of self-satisfaction. As we know that speaking does not only involves the knowledge of speaking but also need the psychological factors. According to Monson (2016), on her research, concerning the strategy use of language in social interaction, this thesis incorporates near ultimate levels of analysis from evolutionary psychology and social sciences to test the hypothesis that language is an adaptation.

Speaking in term of usage is oral communication in expressing ideas to other people as partner of conversation. In other words, the speaker can express his or her ideas through a language. Kosar and Bedir (2014) stated that speaking is the core of a language learning. There is an assumption that successfulness in language learning is discovered by accomplishing acquisition in speaking. According to Leong and Ahmadi (2017), speaking is the foremost skills for the effectiveness of communication. It means that without any speech, communication will not exist. In Oxford Advanced Dictionary (2018), the definition of speaking is to express or communicate opinions, feelings, ideas, etc., by or as talking and it involves the activities in the part of the speaker as psychological (articulator) and physical (aczustic) stages. Based on the explanation above, the researcher concluded that speaking is a thing that use to communicate to each other.

While Byrne (1987) states that oral communication is a two-way process between a speaker and a listener and involves speaking as the productive skills and listening as receptive skills. So both the speakers and the listeners are active during the oral communication take place. It means that a speaker may express his/her mind to the listener, and the listener later will give responses relating to the topic they talk about. The speaker has to encode the message he wishes to convey in the appropriate language. The message itself in normal speech contains some of very important information which is sometimes beyond the listener needs.

According to Harris in Kurniati (2015) stated that there are five components of speaking skill concerned with comprehension, grammar, vocabulary, pronunciation, and fluency.

1. Comprehension. For oral communication, it certainly requires a subject to respond, to speech as well as to initiate it.

2. Grammar. It is needed for the students to arrange a correct sentence in conversation, the students' ability to manipulate structure and to distinguish appropriate grammatical form in appropriateness. The utility of grammar is also to learn the correct way to gain expertise in a language in oral and written form. 
3. Vocabulary. Vocabulary means the appropriate diction which is used in communication. Without having a sufficient vocabulary, one cannot communicate effectively or express his/her ideas both oral and written form. Having limited vocabulary is also a barrier that precludes learners from learning a language. Without grammar very little can be conveyed, without vocabulary nothing can be conveyed.

4. Pronunciation. It is the way for the students to produce clearer language when they speak. It deals with the phonological process that refers to the component of a grammar made up of the elements and principles that determine how sounds vary and pattern in a language. From the statement above, the researcher concluded that pronunciation is the knowledge of studying about how the words in a particular language are produced clearly when people speak. In speaking, pronunciation plays a vital role in order to make the process of communication easy to understand.

5. Fluency. It is the ability to read, speak, or write smoothly and expressively. In other words, the speakers can read, understand, and respond in a language clearly and concisely while relating meaning and content. Fluency can be defined as the ability to speak fluently and accurately. Sign of fluency include a reasonably fast speed of speaking and only a small number of pauses and "ums" or "ers". These signs indicate that the speaker does not have spent a lot of time searching for the language items needed to express the message.

English contest basically is a form of activity of questions and answers in a group dynamics (Sion, 1985). It is an activity of question and answer using English as a medium of instruction conducted by groups, or a kind of quiz activity in English. The contest materials are taken from the third class materials at the first semester which is taken from SMA Curriculum1994 (Supplement GBPP 1999) such as culture/art, community/population, functional skills, etc.

Random House of Webster's College Dictionary (1997) defines self-confidence as the state of feeling sure, when the students or people are able to do things well, self-confidence is faith in one owns' judgment, ability, etc.

Nearly all the available literature suggested self-confidence is very much related to a second language development. All things being equal, the self-confidence, secure people is more successful language learner. Self-confidence learners or students are eager to try new and unpredictable experiences and are willing to guess before knowing for sure, are likely to seek out situations that require real communication in the new language (Jaya Ramlah, 1999). There are some factors which improve the students' self-confidence such as: fluency, vocabulary, grammar, fear and anxiety and shame or shyness.

Alder in Lauser (1997) states that self-confidence is one of the important human being needs. Having high self-confidence someone can do the activity without bothering by a doubtfulness which out of reason frequently. Having self-confidence enables someone to improve their attitude and ability.

In the class setting where teaching and learning process takes place and have to conduct in order a student feel balmy and accepted whatever they are and their condition. Teachers have to create the warm class atmosphere and full of care. The students' ideas, achievement will be accepted, and give appreciation. Students are given ample chance to reach for the successfulness, and whatever his successfulness has to be respected. The students accustomed to the successfulness idea which possible students' self-confidence from time to time will increase (Crabble \& Betts, 1988).

In relation to learning English through contest is a medium and gave a new nuance to attract and to encourage the students' interest. All students who have low ability in speaking will be given the information that they can speak if they have a lot of time to practice. By giving contest is not the final goal in this activity but what the target is to develop speaking skill. English contest enable the students to improve their self-confidence and at the end will increase the students' achievement in learning English.

\section{Method of the Research}


This part contains research design, subject of the research, procedure of action research, data collection and data analysis.

This research was classroom action research and applied ECT in learning English to improve the students' self confidence and speaking skill. This research has two variables, independent variable and dependent variable. ECT is categorized as an independent variable and the dependent variables are the students' speaking skill and self confidence in speaking.

The population of the research was the third grade students which consisted of five classes with 43 students. The researcher took the third grade because the students have studied English for three years and they have got experiences in learning English. The teaching and the procedure of action research consisted of two cycles. Every cycle was conducted in three times and applied the same treatment and the same changes on the second cycle based on the reflection and the result of the first cycle.

The procedure of action research, they are: (1) planning, (2) implementation, (3) observation and evaluation, (4) reflection. After the first and the second meeting then comes the to the evaluation stage. In this there meeting the teacher observes the students' respond in answering the questions. If the students find difficult questions to answer, the teacher as the contest master gives the students a brief explanation. In the reflection stage, after finishing the first cycle, the researcher put a note in a diary about the weaknesses during the contest in the first cycle and made improvement in the second cycle.

The procedure in the second cycle is the same as the first cycle, they are planning, implementation, observation and evaluation and reflection.

The reflection in this research consists of two cycles, the result of the first and the second reflection are to find out the improvement of the students' self-confidence and the students' speaking skills through ECT. In collecting the data, the researcher used questionnaire, interview, field notes, diaries, journal and tape recorder. The questionnaire is used to measure the students' self-confidence which consists of 20 items.

\section{Finding and Discussion}

This chapter deals with the findings of the research and the discussion of the research. The findings are ordered in line with the problem statements stated in the introduction part. The findings of this research reveal the students' self confidence and speaking skills in term of accuracy and fluently through the teaching technique using English contest. Accuracy refers to vocabularies, grammar and accent while fluently refers to the students' performance in front of the classroom. In discussion section/argument and further interpretation of the findings are given.

The application of English contest technique (ECT) as a teaching speaking technique could improve the students' self-confidence as indicated by the students' score of self-confidence in the first and in the second cycle. Based on the result of the first cycle, $7.14 \%$ of the students are categorized very high of self confidence, $42.8 \%$ categorized high, 42.68\% categorized fair and $7.14 \%$ students categorized low of self-confidence. In the second cycle, $14.29 \%$ students categorized very high, $61.90 \%$ categorized high, $21.43 \%$ categorized fair and $2.38 \%$ categorized low. In other words, the mean score in the first cycle is 2.5 which means that the students have high self-confidence and in the second cycle, the mean score is 2.8 which means that the students have high self-confidence too.

The application of English contest technique could develop the students' speaking accuracy as indicated by the students score in cycle one and cycle two. In cycle one, $4.76 \%$ of students are classifiedgood, $73.81 \%$ are classified adequate, $21.43 \%$ are classified marginal and none of them are classified extremely poor. In cycle two, 47.62\%of students are classified good, $50.00 \%$ are classified adequate and $2.38 \%$ are classified marginal and none of them are extremely 
poor classification.

Based on the result, the students' speaking skill on accuracy can be improved by using ECT. The mean score in the first cycle is 5.67 and in the second cycle the mean score is 6.79 which that the speaking accuracy is high.

The implementation of ECT could improve the students' speaking fluency as indicated by the students' score in the first cycle. $50.00 \%$ of students are classified adequate speaker, $42.86 \%$ are classified marginal, $7.14 \%$ of students are classified extremely poor speaker. While in the second cycle, $26.19 \%$ of students are classified good speaker, 57.14\% are classified adequate and $16.67 \%$ of students are classified marginal speaker and none of them are extremely poor.

The result indicated that by ECT could improve the students' fluency in speaking. The mean score in the first cycle is 4.86 (adequate) and in the second cycle, the mean score is 6.19 which mean that the implementation of ECT could improve the students speaking on fluency.

The implementation of English contest technique as a teaching technique could improve the students' speaking skill from the result of the two cycles. In the first cycle, $4.76 \%$ of the students are categorized good, $80.95 \%$ are categorized adequate, $14.29 \%$ are categorized marginal speaker. While in the second cycle, $50.00 \%$ of the students are categorized good speaker, $47.62 \%$ are categorized adequate and $2.38 \%$ are categorized marginal speaker.

The result indicates that the students' speaking skill could improve by implementing ECT. The mean score in the first cycle is 4.29 (adequate) and the mean score of the students in the second cycle is 6.62 which mean that the students' speaking skill is good.

From the about result, the researcher could conclude that there is a significant difference between the first cycle result (5.29) and the mean score result in the second cycle is (6.62). In other words, the H0 is rejected and the H1 is accepted.

In learning particularly speaking, they wanted to get a good point and they want to win the game. The students like what they were doing. They were laughing and applauding when their teams were in contesting and the other team gave support and moral to win the contest.

The ECT gave the students much opportunity in developing their speaking skill by practicing their speaking. The finding also indicated that ECT could develop the students' speaking skill which was seen from the first cycle scores improvement and from the second cycle scores improvement too.

The implementation of ECT is expected to improve the students' self-confidence and finally at the end would increase the students' speaking skill. In other words, learning English through contest is not the final goal in this activity but it is to develop the speaking skill.

\section{Conclusion and Suggestion}

This chapter deals with the conclusion and suggestion of this research.

Based on the result of the data analysis, research findings and discussion in the previous chapter, the researcher formulated the following conclusion:

1. The ECT could improve the students' self confidence in speaking English.

2. The ECT could improve the students' speaking skill in term of accuracy and fluency. It was indicated by the result of the students mean score both in the first cycle and in the second cycle.

3. The ECT as an alternative way in teaching speaking has brought a good nuance and variation in English language teaching particularly teaching speaking.

Related to English language teaching, English Contest Technique (ECT) has been to be an active way to improve the students' self-confidence in speaking English. It suggested for the next researchers to be more creative in preparing an selecting materials to make the learning situation more interesting and motivating. 
The researcher would give some suggestions:

1. The English teachers particularly the senior high school level (SMA) should create, find, and try some techniques as variation of teaching speaking in order to provide an ample opportunity and stimulate the students to communicate orally.

2. The English teachers should be more creative and determine ways and techniques to increase the students' self-confidence in speaking.

3. At the end of the semester, ECT can be considered to implement and the winner is given an interesting reward.

\section{References}

Allien, R. E. (1997). Random House Webster’s College Dictionary, New York: Random House Inc.

Alloysios, Aba. (2012). The Contribution of Self Confidence on the Students Speaking Performance. Unpublished Thesis. Makassar: FBS of State University of Makassar.

Baso. (1995). The Assessment of the Speaking Skill of the Students of English Department of Makassar State University. Unpublished Thesis. Makassar: Hasanuddin State University.

Burns Anne, \& Helen Joyee. (1998). Focus on Speaking. Macquarie: Sydney University, Australia.

Brown. (1994). Teaching by Principles. New Jersey: Prentice Hall Regents, Inc.

Harris in Kurniatii. (2015). A study on the Speaking Ability of the Second Year Students of SMK TelkomPekan Baru. Journal online Mahasiswa fakultas Keguruan dan IlmuPendidikan. Vol. 2 No. 22015.

Hariyati. (2018). The Use of Ice Breakers to Improve EFL Learners Speaking Ability. Vol. 2 No. 2. 2018.

Kosar \& Bedir. (2014). Strategies based Instruction: A means of Improving Adult EFL Learners' Speaking Skill. International Journal of Language Academy, 2, 2342-0251. Accessed at 6th. October 2019.

Leonga \& Ahmadi. (2017). An analysis of Factors Influencing Learners’ English Speaking Skill. International Journal of Research in English Education. Vol. 2 Issued 1. (3-2017) Accessed at 6th. October. 2019.

Monson. (2016). Two Truths and a Lie: An Evolutionary Basis for Strategic Use of a Language. Academia. Accessed at 4th. October 2019.

Nelson \& Pearson. (1993). Confidence in Public Speaking. London: Brown and BenchmarkHarper Collins Publishers Inc.

Noni, Nurdin. (2000). Peningkatan Penguasaan Keterampilan Keterampilan Bertanya BagiGuru SMPN 8 Makassar Untuk Mempasilitasi Pembelajaran Bahasa I nngris Siswa. Makassar: Action Research.

Noni, Nurdin. (2003). A Hybrid of Face to Face Teaching Computer Assisted Language Learningin ELT Based on Individual Preferences. Unpublished Thesis Makassar: Hasanuddin University.

Oxford Advanced Dictionary. (2018). www.oxforddictionaries.com. Accessed at 6th. 2019.

Penny. (2016). 100 Teaching Tips: Cambridge: Scoot Thormbury. 